\title{
Development of reverse-transcription loop-mediated isothermal amplification assay (RT-LAMP) for the detection of Barley yellow mosaic virus
}

\author{
Opracowanie metody odwrotnej transkrypcji \\ i izotermalnej amplifikacji DNA z zastosowaniem starterów \\ zapętlających (RT-LAMP) do wykrywania wirusa żółtej mozaiki jęczmienia \\ (Barley yellow mosaic virus)
}

\author{
Natasza Borodynko*, Małgorzata Jeżewska
}

\begin{abstract}
Summary
Barley yellow mosaic virus (BaYMV) is the causal agent of a dangerous disease of winter barley, identified in Poland for the first time in 2008. It is transmitted by a root-inhabiting fungal-like plasmodiophorid Polymyxa graminis Led, and thus the disease is called "soil-borne". Taking into account the way of transmission of the pathogen, the only method of protection of winter barley crops against this pathogen is breeding and cultivation of resistant/tolerant cultivars. The objective of investigations presented in this paper was to develop an improved efficient diagnostic molecular method for precise detection of BaYMV in assessed materials. For the first time a reverse-transcription loop-mediated isothermal amplification assay (RT-LAMP) was chosen and adopted for improved diagnostics of BaYMV. The specific RT-LAMP primers for BaYMV detection were designed based on the coat protein gene. RT-LAMP assay is inexpensive and easy to perform, so it may be used for the rapid and specific diagnosis of BaYMV.
\end{abstract}

Key words: Barley yellow mosaic virus; winter barley; diagnostics; RT-LAMP

\section{Streszczenie}

Wirus żółtej mozaiki jęczmienia (Barley yellow mosaic virus, BaYMV) jest sprawcą niebezpiecznej choroby jęczmienia ozimego. W Polsce po raz pierwszy został zidentyfikowany w 2008 roku. BaYMV jest przenoszony przez pierwotniaka glebowego Polymyxa graminis Led. i dlatego wiroza określana jest jako "odglebowa”, a jedynym sposobem jej zwalczania pozostaje hodowla i uprawa odmian odpornych/tolerancyjnych. Celem badań było opracowanie bardziej czułych, molekularnych metod diagnostycznych, pozwalających na precyzyjną ocenę porażeń roślin przez wirus. Po raz pierwszy zaadaptowano molekularną technikę odwrotnej transkrypcji i izotermicznej amplifikacji DNA z zastosowaniem starterów zapętlających (RT-LAMP - reverse-transcription loopmediated isothermal amplification assay) i wykazano możliwość jej wykorzystania w diagnostyce BaYMV. Specyficzne startery zaprojektowano w oparciu o sekwencję nukleotydów genu kodującego białko płaszcza. RT-LAMP ze względu na niskie koszty wykonania, jak i szybkość reakcji może być wykorzystywany do szybkiej i specyficznej diagnostyki wirusa.

Słowa kluczowe: wirus żółtej mozaiki jęczmienia; jęczmień ozimy; diagnostyka; RT-LAMP

Instytut Ochrony Roślin - Państwowy Instytut Badawczy

Zakład Wirusologii i Bakteriologii

Władysława Węgorka 20, 60-318 Poznań

*corresponding author: n.borodynko@iorpib.poznan.pl 


\section{Wstęp / Introduction}

Żółta mozaika jęczmienia jest ekonomicznie ważną chorobą jęczmienia ozimego, wywoływaną przez dwa wirusy: żółtej mozaiki jęczmienia (Barley yellow mosaic virus, BaYMV) oraz łagodnej mozaiki jęczmienia (Barley mild mosaic virus, BaMMV). Występuje w Europie i Azji (Plumb i wsp. 1986; Kühne 2009). W Europie BaYMV został po raz pierwszy stwierdzony w Wielkiej Brytanii w latach 80. XX wieku, a obecnie jest wykrywany w większości upraw jęczmienia ozimego w Europie (Hill i Walpole 1989; Adams 1991). W Polsce BaYMV został zidentyfikowany w 2008 roku (Jeżewska i Trzmiel 2009). Prowadzony w kolejnych latach monitoring występowania wirusów na jęczmieniu ozimym wykazał, że głównym sprawcą choroby jest BaYMV (Jeżewska i wsp. 2010). Dotychczasowe badania wykazały, że jedynym skutecznym sposobem walki $\mathrm{z}$ chorobą jest stosowanie odmian odpornych na BaYMV (Adams i wsp. 1987; Hill i wsp. 1988).

Wirus należy do rodzaju Bymovirus (rodzina Potyviridae), a jego wektorem jest pierwotniak glebowy Polymyxa graminis Led. (Adams i wsp. 1988). Przenosi się także mechanicznie. Cząstki wirusa są nitkowate (Huth i wsp. 1984), a genom dwudzielny i obejmuje RNA1 i RNA2 o wielkościach odpowiednio 7,6 i 3,5 kb (Chen i wsp. 1999). RNA1 koduje pojedynczą poliproteinę, z której w wyniku cięcia wirusowymi proteazami powstaje dziesięć białek, w tym białko płaszcza (CP - coat protein) (Berger i wsp. 2005). RNA2 również koduje jedną poliproteinę, z której powstają dwa białka: P1 (niezbędne do wywołania infekcji systemicznej) i P2 (warunkujące przenoszenie przez wektora) (You i Shirako 2012).

W diagnostyce BaYMV stosowano: ELISA (enzymelinked immunosorbent assay) (Adams 1991), RT-PCR (reverse transcription and polimerase chain reaction) (Vaïanopoulos i wsp. 2003) czy real time PCR (polimerase chain reaction) z sondą TaqMan (Mumford i wsp. 2004). Chociaż są to metody powszechnie stosowane w diagnostyce wirusów, w ostatnich latach opracowano nową metodę LAMP (Loop-mediated isothermal AMPlification), która charakteryzuje się wysoką czułością i specyficznością, a dodatkowo pozwala na szybką identyfikację wirusa (około 45 minut). Nie wymaga specjalistycznego sprzętu, $\mathrm{z}$ powodzeniem może być zastosowana $\mathrm{z}$ wykorzystaniem łaźni wodnej. Dotychczas technikę tę stosowano m.in. w diagnostyce wirusa mozaiki ogórka (Cucumber mosaic virus, CMV) (Peng i wsp. 2012), wirusa mozaiki pepino (Pepino mosaic virus, PepMV) (Hasiów-Jaroszewska i Borodynko 2013) oraz wirusa nekrotycznej pierścieniowej plamistości wiśni (Prunus necrotic ringspot virus, PVRSV) (Zong i wsp. 2014).

Celem pracy było opracowanie warunków zastosowania metody RT-LAMP (reverse-transcription loop-mediated isothermal amplification assay) $\mathrm{w}$ diagnostyce wirusa żółtej mozaiki jęczmienia.

\section{Materiały i metody / Materials and methods}

Do badań użyto niemiecki izolat BaYMV, Glen Torf Gruppe1, otrzymany z The Institute for Epidemiology and
Pathogen Diagnostics, Federal Research Centre for Cultivated Plants - Julius Kuehn Institute (BAZ) w Quedlinburgu (Niemcy). Wirusa utrzymywano na jęczmieniu odmiany Gil lub Merlot. Rośliny w fazie 3 liści inokulowano mechanicznie wirusem. W tym celu liście porażonych roślin rozcierano w $0,05 \mathrm{M}$ buforze fosforanowym, a następnie otrzymanym sokiem zakażano zdrowe rośliny, opylone wcześniej karborundem. Rośliny utrzymywano w stałych warunkach temperatury $\left(12^{\circ} \mathrm{C}\right.$ w nocy, $15^{\circ} \mathrm{C}$ w dzień). Ze $100 \mathrm{mg}$ próbek przygotowanych $\mathrm{z}$ roślin wykazujących objawy chorobowe izolowano całkowity RNA, stosując zestaw RNeasy®Plant Mini Kit (Qiagen), zgodnie z zaleceniami producenta. Uzyskane RNA mierzono na spektrofotometrze i doprowadzano stężenie do $0,5 \mu \mathrm{g} / \mu \mathrm{l}$. Otrzymany całkowity RNA przechowywano w temperaturze $-20^{\circ} \mathrm{C}$.

Startery do reakcji LAMP zaprojektowano w oparciu o sekwencję nukleotydów genu kodującego białko płaszcza (Kühne i wsp. 2003; Nishigawa i wsp. 2008) z wykorzystaniem programu Primer Explorer V4 software (http://primerexplorer.jp/e/v4_manual/index.html). Sekwencje nukleotydów $\mathrm{CP}$ dla trzech różnych izolatów BaYMV uzyskano z Banku Genów.

W reakcji RT-LAMP użyto następujące startery: zewnętrzny forward F3 (GGCAACGAAGCAAGTTAAC), zewnętrzny reverse B3 (GCATTACTTGATTCTCAG CATG), wewnętrzny forward FIP (CACAGCATCAGT CCAGGCTTGCCTAAGTCTGTTATGGAACAT), wewnętrzny reverse BIP (ACAACTGATGAGGCATGGATCG TGAGGTGCCATTGTTGC), zapętlający forward LoopF (AGATTCGAGTGCAACTGAGTT) oraz zapętlający reverse LoopB (CCTTCATCGGATGGTGCT). Reakcję prowadzono w $25 \mu$, a mieszanina zawierała: $2 \mu \mathrm{M}$ FIP i $2 \mu \mathrm{M}$ BIP, $0,5 \mu \mathrm{M}$ F3 i $0,5 \mu \mathrm{M}$ B3, $1 \mu \mathrm{M}$ LoopF i $1 \mu \mathrm{M}$ LoopB, $15 \mu$ Isothermal Mastermix (ISO-001t) (Novazym), $20 \mathrm{U}$ odwrotnej transkryptazy (ROCHE), $2 \mu 1$ RNA oraz $1 \mu$ l wody. Reakcję prowadzono zgodnie $\mathrm{z}$ protokołem producenta, w temperaturze $65^{\circ} \mathrm{C}$ przez 45 minut. Reakcję prowadzono w aparacie do reakcji real time PCR (Mx3000P, Stratagene) umożliwiającym analizę przyrostu produktu w czasie (w kolejnych cyklach). Do amplifikacji produktów wykorzystano również łaźnię wodną i termoblok, w których utrzymywano stałą temperaturę. Uzyskane produkty amplifikacji wykrywano po rozdziale elektroforetycznym w 1\% żelu agarozowym z dodatkiem barwnika Midori Green DNA Stain (Nippon Genetics Europe $\mathrm{GmbH})$.

W celu potwierdzenia specyficzności zastosowanych starterów do reakcji RT-LAMP identyfikowano również materiał genetyczny innych wirusów porażających jęczmień: wirusa pasiastej mozaiki jęczmienia (Barley stripe mosaic virus, BSMV) oraz grupę wirusów żółtej karłowatości jęczmienia (Barley yellow dwarf virus-PAV, Barley yellow dwarf virus-MAV i Cereal yellow dwarf virus$R P V)$.

W celu przeprowadzenia konwencjonalnej reakcji RTPCR zaprojektowano startery w obrębie regionów konserwatywnych obejmujących sekwencje nukleotydów genu kodującego białko płaszcza (BaYMV CPF: GCAGCCAT GACTCAATCCTC i BaYMV CPR: GGGTGATGGTTT AGGTTAGTTC). 
RT-PCR przeprowadzono jednoetapowo z wykorzystaniem zestawu Transcriptor One-Step RT-PCR (Roche) zgodnie $\mathrm{z}$ zaleceniami producenta. Reakcję odwrotnej transkrypcji prowadzono $\mathrm{W}$ temperaturze $50^{\circ} \mathrm{C}$ przez 30 min. Następnie, po wstępnej denaturacji w $94^{\circ} \mathrm{C}$ przez 7 min, przeprowadzono 35 cykli PCR: denaturacja $94^{\circ} \mathrm{C}$ przez $30 \mathrm{~s}$; przyłączanie starterów: $57^{\circ} \mathrm{C}$ przez $30 \mathrm{~s}$; wydłużanie nici $68^{\circ} \mathrm{C}$ przez 1 min oraz końcowe wydłużenie w $68^{\circ} \mathrm{C}$ przez 7 min.

Otrzymane produkty amplifikacji rozdzielano na $1 \%$ żelu agarozowym z dodatkiem barwnika Midori Green DNA Stain (Nippon Genetics Europe GmbH). Produkty oczyszczano z żelu za pomocą NucleoSpin ${ }^{\circledR}$ Gel and PCR Clean-up (Machery-Nagel), zgodnie z zaleceniami producenta, ligowano do wektora pGEM T-Easy (Promega) i przeprowadzano transformację metodą szoku termicznego do komórek kompetentnych Escherichia coli TOP10 (Invitrogen). Plazmidowe DNA izolowano z użyciem zestawu NucleoSpin ${ }^{\circledR}$ Plasmid (NoLid) (Machery-Nagel), a obecność insertów weryfikowano poprzez trawienie enzymem restrykcyjnym EcoRI (Thermo Scientific). DNA sekwencjonowano $\mathrm{w}$ firmie Genomed S.A. $\mathrm{z}$ użyciem uniwersalnych starterów M13F/R w celu poznania sekwencji wirusa, stwierdzenia jej poprawności oraz porównania $\mathrm{z}$ innymi sekwencjami dostępnymi w Banku Genów. Porównywano czułość testów RT-PCR, RTLAMP i real time RT-LAMP do wykrywania wirusa, stosując serię dziesięciokrotnych rozcieńczeń całkowitego RNA o stężeniu $500 \mathrm{ng} / \mu 1$.

\section{Wyniki i dyskusja / Results and discussion}

Potrzeba adaptacji metody RT-LAMP do wykrywania BaYMV wyniknęła z niewystarczającej czułości wykrywania tego wirusa $\mathrm{w}$ roślinach jęczmienia ozimego w Polsce z zastosowaniem testu ELISA. Badania obejmowały diagnostykę wirusa zarówno w zakresie monitoringu w naturalnych warunkach polowych, jak i doświadczeń nad oceną odporności odmian zalecanych do uprawy w naszym kraju (Jeżewska i wsp. 2010; Jeżewska 2013). Wyniki otrzymane przy zastosowaniu testu ELISA wykazywały niskie odczyty absorbancji dla testowanych prób roślinnych. Produkty uzyskane w wyniku RT-LAMP są mieszaniną fragmentów DNA o różnej wielkości i różnej strukturze. Potwierdził to obraz elektroforezy, przeprowadzonej po amplifikacji wykonanej w łaźni wodnej (rys. 1), w obecności markera wielkości DNA. Dla sześciu kolejnych rozcieńczeń całkowitego RNA uzyskano produkty reakcji, nie uzyskano natomiast produktu dla stężenia $500 \mathrm{fg}$.

Specyficzność metody potwierdzono w reakcji real time RT-LAMP, w trakcie której otrzymano jeden produkt amplifikacji, taki sam dla poszczególnych rozcieńczeń. Nie uzyskano produktów amplifikacji dla innych testowanych wirusów porażających jęczmień. Uzyskane wyniki przedstawiono w formie wykresów krzywych amplifikacji i krzywych topnienia (rys. 2, 3). Podobną czułość reakcji uzyskano $\mathrm{w}$ porównaniu $\mathrm{z}$ konwencjonalną reakcją RT-PCR

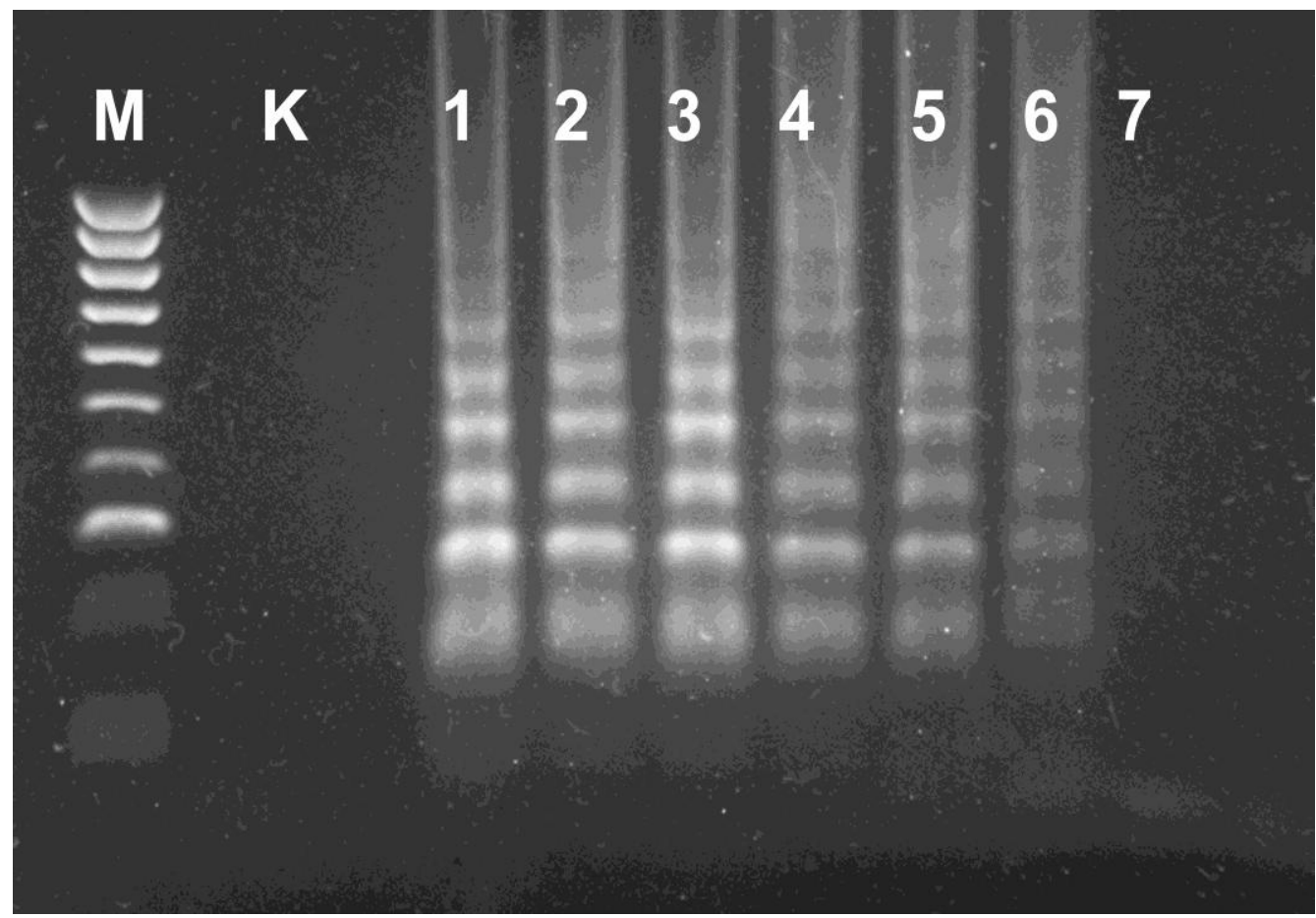

Rys. 1. Wykrywanie BaYMV z zastosowaniem techniki RT-LAMP, w kolejnych rozcieńczeniach całkowitego RNA

M - marker HyperLadder IV(Bioline), K - kontrola negatywna, 1-7 - kolejne rozcieńczenia: 500 ng, 50 ng, 5 ng, 500 pg, 50 pg, $5 \mathrm{pg}, 500 \mathrm{fg}$

Fig. 1. Detection of BaYMV by RT-LAMP assay using of serial dilutions of the RNA

$\mathrm{M}$ - HyperLadder IV (Bioline), K - negative control, 1-7 - serial dilutions: 500 ng, $50 \mathrm{ng}, 5 \mathrm{ng}, 500$ pg, 50 pg, 5 pg, 500 fg 


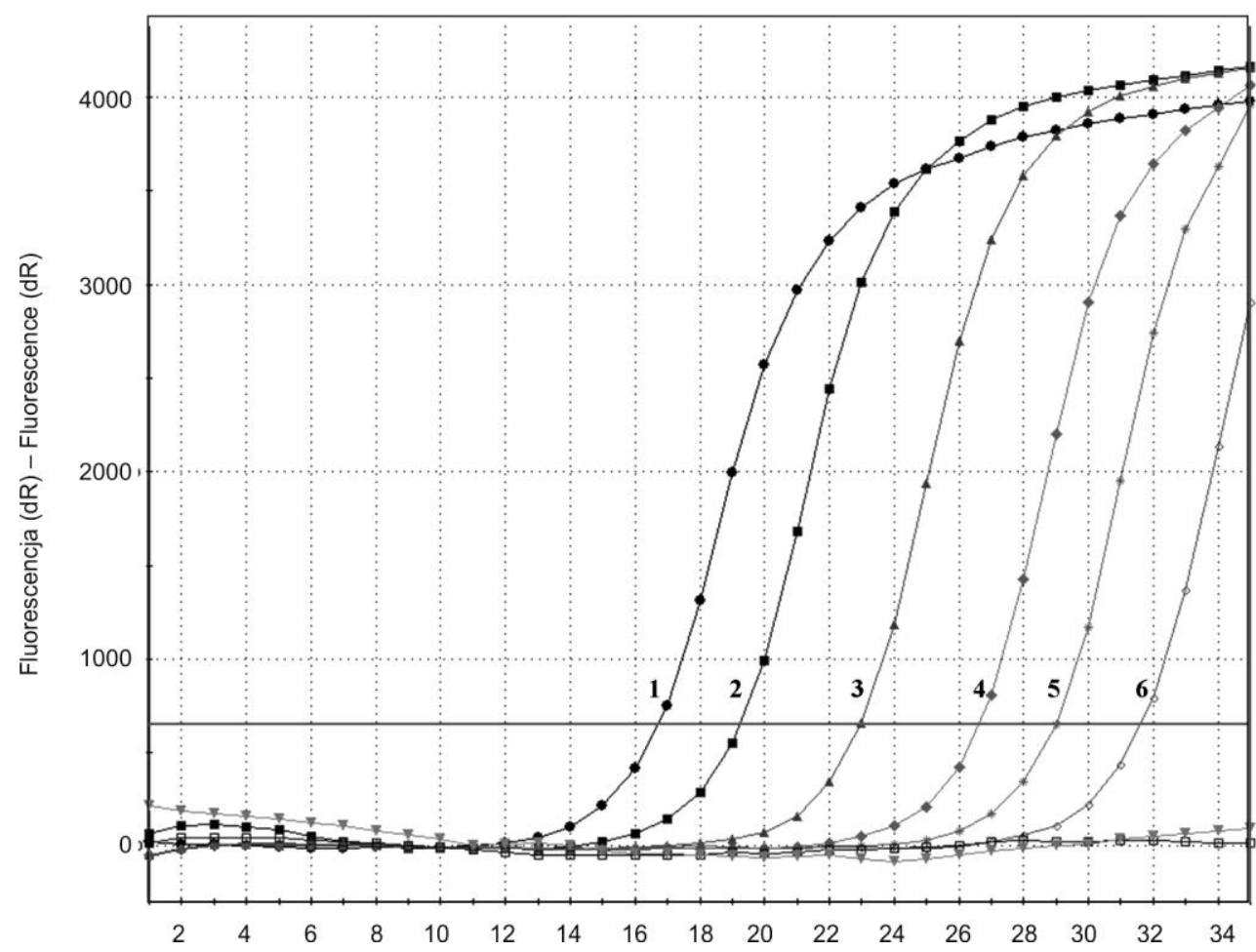

Rys. 2. Krzywe amplifikacji obserwowane w czasie rzeczywistym. 1-6 - kolejne rozcieńczenia Fig. 2. Amplification curves monitoring in real time. 1-6- serial dilutions

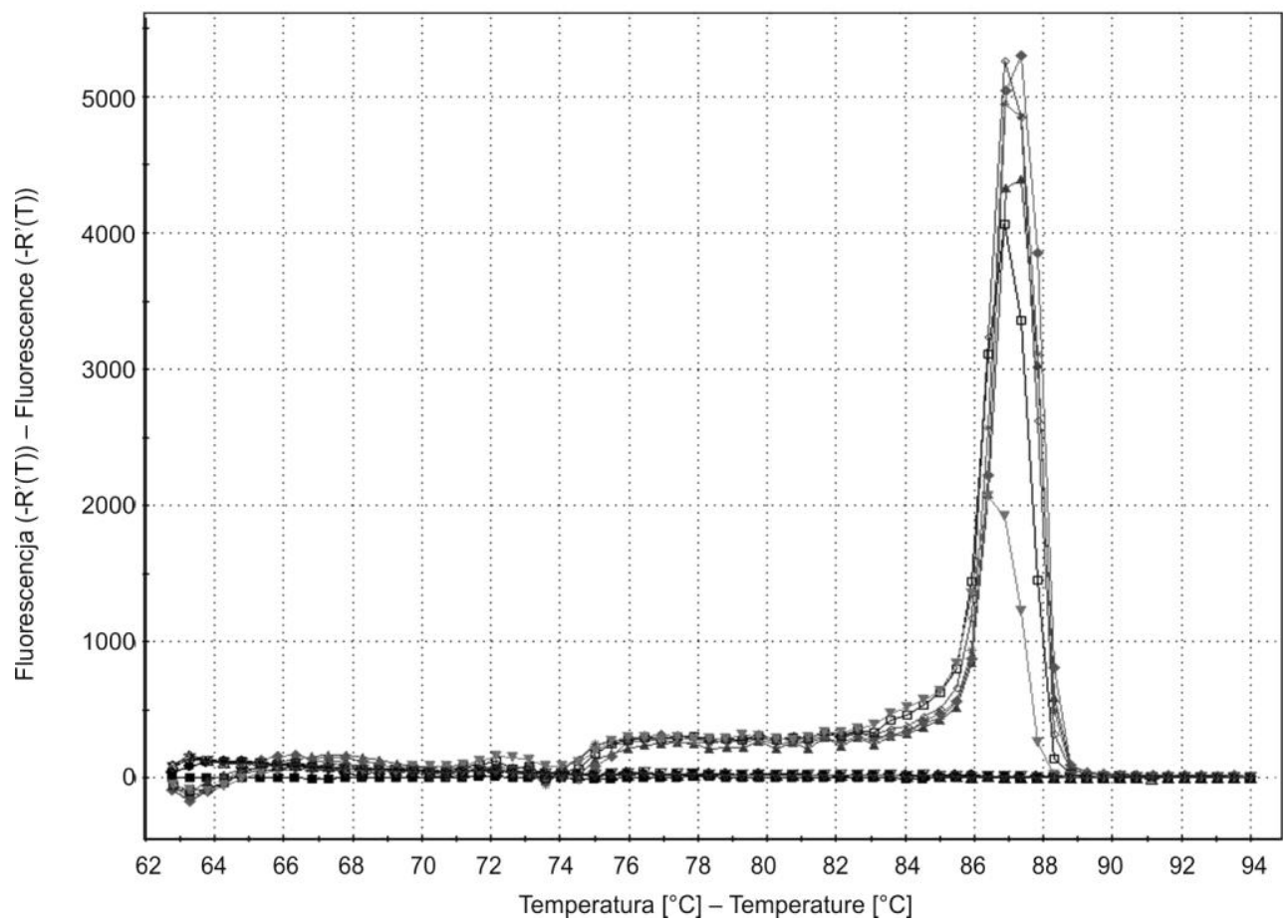

Rys. 3. Krzywe topnienia dla 6 kolejnych rozcieńczeń. Dla wszystkich rozcieńczeń uzyskano takie same produkty amplifikacji Fig. 3. Six dissociation curves for serial tenfold dilutions. The same amplification products for all dilutions tested

(rys. 4), jednak ze względu na krótki czas reakcji, metoda RT-LAMP okazuje się być szczególnie przydatna w zastosowaniu do prób wymagających szybkiej diagnostyki.
Przedstawione dane wykazały podobną czułość technik RT-PCT, RT-LAMP i real-time RT-LAMP. Trudno jednoznacznie to wyjaśnić, ale można przypuszczać, że we 


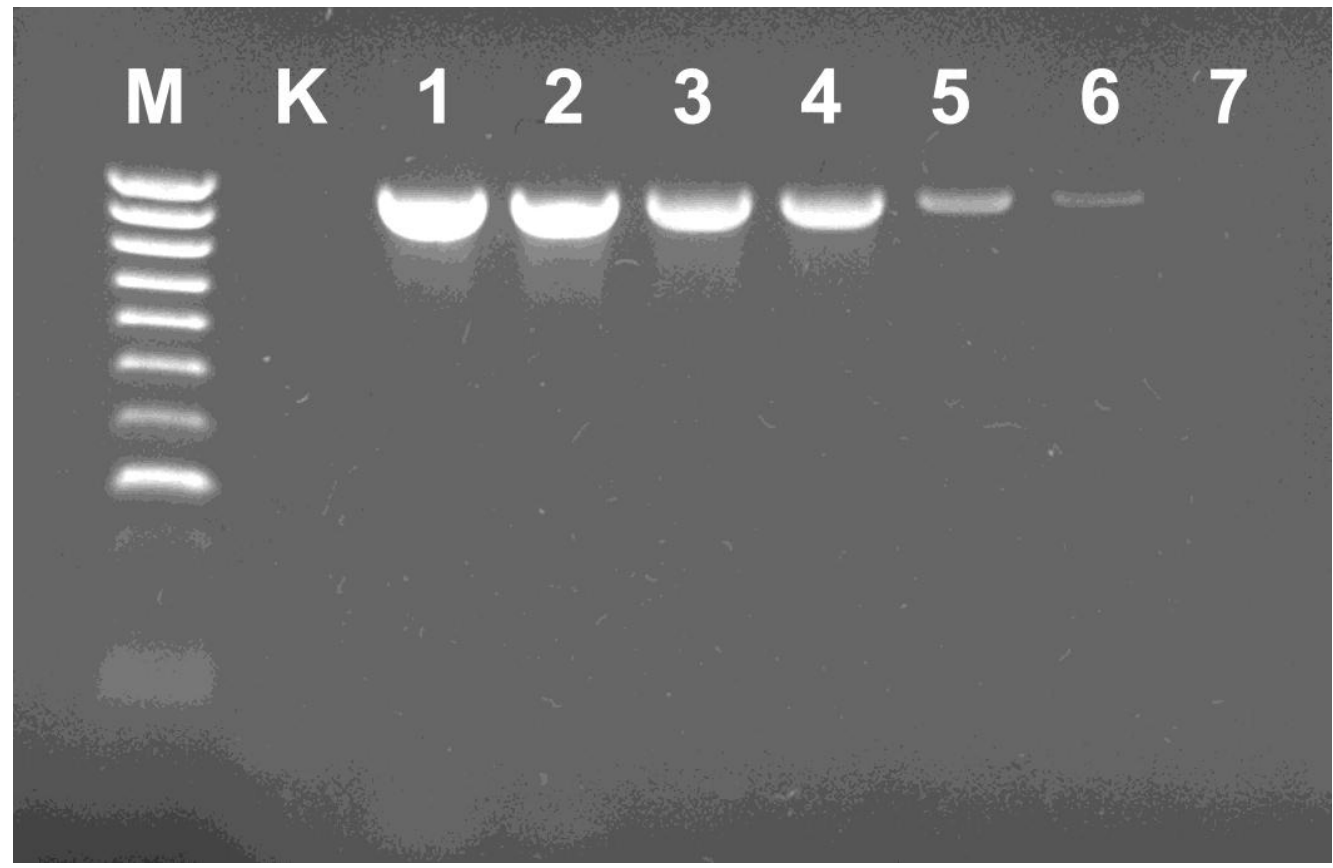

Rys. 4. Wykrywanie BaYMV z zastosowaniem konwencjonalnego RT-PCR

M - marker HyperLadder IV(Bioline), K - kontrola negatywna, 1-7 - kolejne rozcieńczenia: 500 ng, 50 ng, 5 ng, 500 pg, 50 pg, $5 \mathrm{pg}, 500 \mathrm{fg}$

Fig. 4. Detection of BaYMV using RT-PCR

M - HyperLadder IV (Bioline), K - negative control, 1-7 - serial dilutions: 500 ng, 50 ng, 5 ng, 500 pg, 50 pg, 5 pg, 500 fg

wszystkich przypadkach osiągnięto graniczny poziom wykrywania wirusa.

Jedyną trudność w przypadku tej techniki stanowi etap projektowania trzech par starterów, które wymagają długich sekwencji nukleotydów, jednak dostępne są programy (również bezpłatne), które ułatwiają dobór sekwencji starterów tak, żeby zachowana została ich wysoka specyficzność.

Możliwość wykrycia wirusa metodą RT-LAMP w preparatach rozcieńczonych do 500 fg świadczy o czułości testu, co nie zawsze musi odpowiadać skuteczności detekcji BaYMV w materiale roślinnym. Uzasadnione jest podjęcie dalszych badań $\mathrm{w}$ celu weryfikacji przydatności metody w praktyce.

\section{Wnioski / Conclusions}

1. Zaprojektowane startery do testu RT-LAMP w sposób specyficzny wykrywają BaYMV.

2. Opracowana technika RT-LAMP pozwala na uzyskanie wyniku w ciągu 45 minut i nie wymaga specjalistycznego oraz drogiego sprzętu.

\section{Podziękowanie / Acknowledgements}

Praca naukowa finansowana ze środków na naukę z Narodowego Centrum Nauki w latach 2011-2014 jako projekt badawczy NN 310724840 .

\section{Literatura / References}

Adams M.J. 1991. The distribution of barley yellow mosaic virus (BaYMV) and barley mild mosaic virus (BaMMV) in UK winter barley samples, 1987-1990. Plant Pathology 40: 53-58.

Adams M.J., Jones P., Swaby A.G. 1987. The effect of cultivar used as host for Polymyxa graminis on the multiplication and transmission of barley yellow mosaic virus (BaYMV). Annals of Applied Biology 110: 321-327.

Adams M.J., Swaby A.G., Jones P. 1988. Confirmation of the transmission of barley yellow mosaic virus (BaYMV) by the fungus Polymyxa graminis. Annals of Applied Biology 112: 133-141.

Berger P.H., Adams M.J., Barnett O.W., Brunt A.A., Hammond J., Hill J.H., Jordan R.L., Kashiwazaki S., Rybicki E., Spence N., Stenger D.C., Ohki S.T., Uyeda L., van Zaayen A., Valkonen J., Vetten H. 2005. Family Potyviridae. p. 819-841. In: "Virus Taxonomy. Eighth Report of the International Committee on Taxonomy of Viruses" (C.M. Fauquet, M.A. Mayo, J. Maniloff, U. Desselberger, L.A. Ball, eds.). Elsevier Academic Press, San Diego, CA, 1259 pp.

Chen J., Shi N., Cheng Y., Diao A., Chen J., Wilson T.M.A., Antoniw J.F., Adams M.J. 1999. Molecular analysis of barley yellow mosaic virus isolates from China. Virus Research 64: 13-21.

Hasiów-Jaroszewska B., Borodynko N. 2013. Detection of Pepino mosaic virus isolates from tomato by one-step reverse transcription loop-mediated isothermal amplification. Archives of Virology 158 (10): 2153-2156.

Hill S.A., Jones D.E., Popple S.C., Cook R.J. 1988. The resistance of winter barley cultivars to Barley yellow mosaic virus. Annals of Applied Biology 112: 74-75. 
Hill S.A., Walpole B.J. 1989. National and local spread of barley yellow mosaic virus in the United Kingdom. Bulletin OEPP/EPPO Bulletin 19: 555-562.

Huth W., Lessemann D.E., Paul H.L. 1984. Barley yellow mosaic virus: purification, electron microscopy, serology, and other properties of two types of the virus. Journal of Phytopathology 111: 37-54.

Jeżewska M. 2013. Wpływ warunków pogodowych na występowanie wirusa żółtej mozaiki jęczmienia (Barley yellow mosaic virus, BaYMV) w Polsce oraz ocena podatności odmian jęczmienia ozimego na zakażenie. [Impact of temperature and rainfall on symptom expression of barley yellow mosaic in Poland and preliminary assessment of the reaction of winter barley cultivars to the virus]. Progress in Plant Protection/Postępy w Ochronie Roślin 53 (2): 409-412.

Jeżewska M., Cajza M., Buchowska-Ruszkowska M. 2010. Monitoring i diagnostyka molekularna wirusów zbóż. s. 157-180. W: „Ograniczanie strat w plonach roślin uprawnych z zachowaniem bezpieczeństwa żywności” (D. Sosnowska, red.). Instytut Ochrony Roślin - PIB, 284 ss.

Jeżewska M., Trzmiel K. 2009. First report of Barley yellow mosaic virus infecting barley in Poland. Plant Pathology 58 , p. 784.

Kühne T. 2009. Soil-borne viruses affecting cereals - Known for long but still a threat. Virus Research 141: 174-183.

Kühne T., Shi N., Proeseler G., Adams M.J., Kanyuka K. 2003. The ability of a bymovirus to overcome the rym4-mediated resistance in barley correlates with a codon change in the VPg coding region on RNA1. Journal of General Virology 84: 2853-2859.

Mumford R., Skelton A., Metcalf E., Walsh K., Boonham N. 2004. The reliable detection of Barley yellow and mild mosaic viruses using real-time PCR (TaqMan). Journal of Virology Methods 117: 153-159.

Nishigawa H., Hagiwara T., Yumoto M., Sotome T., Kato T., Natsuaki T. 2008. Molecular phylogenetic analysis of Barley yellow mosaic virus. Archives of Virology 153 (9): 1783-1786.

Peng J., Shi M., Xia Z., Huang J., Fan Z. 2012. Detection of cucumber mosaic virus isolates from banana by reverse transcription loopmediated isothermal amplification. Archives of Virology 157: 2213-2217.

Plumb R.T., Lennon E.A., Gutteridge R.A. 1986. The effects of infection by Barley yellow mosaic virus on the yield and components of yield of barley. Plant Pathology 35: 314-318.

Vaïanopoulos C., Legreve A., Barbier A., Steyer S., Maraite H., Bragard C. 2003. Detection of Barley yellow mosaic virus and Barley mild mosaic virus by RT-PCR on resistance barley cultivars. Parasitica 59 (3-4): 67-74.

You Y., Shirako Y. 2012. Evaluation of host resistance to Barley yellow mosaic virus infection at the cellular and whole-plant levels. Plant Pathology 62: 226-232.

Zong X., Wang W., Wei H., Wang J., Chen X., Xu L., Zhu D., Tan Y., Liu Q. 2014. Rapid detection of Prunus necrotic ringspot virus using magnetic nanoparticle-assisted reverse transcription loop-mediated isothermal amplification. Journal of Virological Methods 208: 85-89. 